\author{
Citation: Özdenizci Köse, B. (2019), An Analysis On The Role Of Social Network Structure In \\ IT Outsourcing Project Realization, BMIJ, (2019), 7(5): 2052-2072 doi: \\ http://dx.doi.org/10.15295/bmij.v7i5.1268
}

\title{
AN ANALYSIS ON THE ROLE OF SOCIAL NETWORK STRUCTURE IN IT OUTSOURCING PROJECT REALIZATION
}

Büşra ÖZDENIZCİ KÖSE ${ }^{1}$
Received Date (Başvuru Tarihi): 12/09/2019

Accepted Date (Kabul Tarihi): 26/10/2019

Published Date (Yayın Tarihi):25/12/2019

\begin{abstract}
Information Technology (IT) outsourcing practices are increasing due to valuable strategic benefits such as cost savings, value-added activities, high quality systems, risk reduction, efficiency and competitiveness, compliance and security, and more. Today, managing the outsourcing relationship between client and vendor has become one of the significant issues to be considered for the sustainability of outsourcing interaction and the success of project outcomes. This study examines the importance of social interaction structure on project success and examines how relationship dynamics are realized between the client and vendor side through a case of "failed" IT outsourcing project. This case study puts forward the importance of IT outsourcing on project success with an interpretive analysis. In this regard, the study examines the IT outsourcing project participants' needs, the communication dynamics and the social network model in terms of structural and tie properties; and sheds light on the hidden issues of failed IT outsourcing projects for practitioners and researchers.
\end{abstract}

Keywords: IT Outsourcing, Social Network, Tie Measures, Structural Measures, Case Analysis

JEL Codes: M15, O22, G34

\section{BT DIŞ KAYNAK KULLANIMI PROJESINIIN GERÇEKLEŞMESINDE SOSYAL AĞ YAPISININ ROLÜ ÜZERİNE BİR İNCELEME}

$\ddot{O} Z$

Bilgi Teknolojileri (BT) dlş kaynak kullanım faaliyetleri, maliyet tasarrufu, katma değerli faaliyetler, yüksek kaliteli sistemler, risk azaltma, verimlilik ve rekabet gücü, uyumluluk ve güvenlik gibi sağladı̆̆ değerli stratejik faydalar nedeniyle giderek artmaktadır. Günümüzde, müşteri ile sağlayıcı arasındaki dış kaynak ilişkisini yönetmek, dlş kaynak etkileşiminin sürdürülebilirliği ve proje başarısı için göz önünde bulundurulması gereken önemli konulardan biri haline gelmiştir. Bu çallş̧a, sosyal etkileşim yapısinin proje başarısındaki önemini ve "başarısız" bir IT dlş kaynak projesi örneğinde müşteri ile satıcı arasındaki ilişki dinamiğinin nasıl gerçekleştiğini incelemektedir. Bu vaka incelemesi, BT dış kaynak kullanımı ilişsisinin proje başarısı üzerindeki önemini yorumlayıcı bir analizle ortaya koymaktadır. Bu bağlamda, bu çalışma dış kaynak proje katıllımcllarının ihtiyaçlarını, iletişim dinamiklerini ve sosyal ă̆ modelini yapısal ve bağ özellikleri bakımından incelemektedir; uygulayıcılar ve araştırmacılar için başarısız BT dış kaynak projelerinin gizli sorunlarına ışık tutmaktadır.

Anahtar Kelimeler: BT Dış Kaynak Kullanımı, Sosyal Ăg, Bă̆ Ölçütleri, Yapısal Ölçüler, Vaka İncelemesi

JEL Kodlart: M15, O22, G34

\footnotetext{
${ }^{1}$ Asst. Prof., Gebze Technical University, busraozdenizci@gtu.edu.tr
} 


\section{INTRODUCTION}

Information Technologies (IT) or Information Systems (IS) outsourcing practices have been growing rapidly in recent years and seem to continue as executives concentrate on partnerships to take advantage of various strategic benefits of outsourcing activity such as cost savings, value-added activities, high quality systems, risk reduction, efficiency and competitiveness (Loh and Venkatraman, 1995; Hu et al., 1997; Kern and Willcocks, 2002; Djavanshir, 2005; Cunden, 2008). Weinert and Meyer state that "outsourcing" word is composed of the words "outside", "resource" and "using" which means the transfer of activities previously performed in-house to external vendors (Weinert and Meyer, 2005: 1). Outsourcing should be considered as an externalization of non-core, routine tasks (Weinert and Meyer, 2005: 1-3) or externalization of strategic tasks (Insinga and Werle, 2000: 2-3) that will ensure competitive advantage for the business operations and assets in an organization having the weak internal capability. According to Gartner (Gartner, 2008), the big majority of the European organizations outsource to benefit from low costs and to improve cash flow within the organization, and also to gain access to resources and capabilities. Similarly, the analysis of Statista puts forward similar IT outsourcing drivers in 2018. As shown in Figure 1, the top reasons for IT service outsourcing is to access non-core skills and resources in-house, to achieve cost savings and also to improve scalability and flexibility (Statista, 2018).

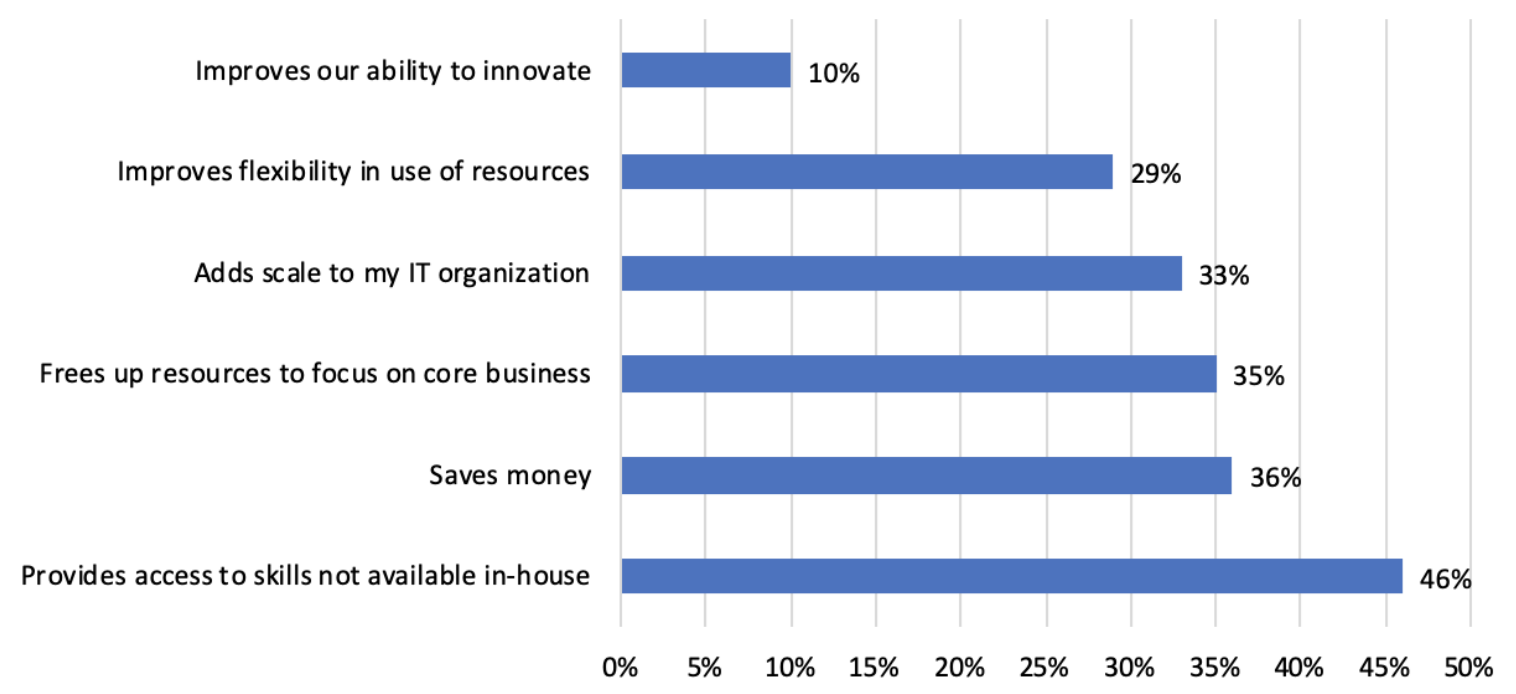

Figure 1. Top Reasons of IT Outsourcing Worldwide in 2018 (Statista, 2018)

Outsourcing can be described as the "make-versus-buy decision facing a firm" (Loh and Venkatraman, 1992: 9). As part of outsourcing, the term IT outsourcing can be defined as the transfer of various IT activities (e.g., computer and Internet-related tasks, programming, 
infrastructure, utility services, etc.) to external vendors (Weinert and Meyer, 2005). IT outsourcing has been variously defined in the literature. Some of the challenging definitions are as follows: IT outsourcing "is the significant contribution by external vendors in the physical and/or human resources associated with the entire or specific components of the IT infrastructure in the user organization" (Loh and Venkatraman, 1992: 9); "is business practice in which a company contracts all or part of its information systems operations to one or more outside information service suppliers; this is done to acquire economic, technological and strategic advantages" (Hu et al., 1997: 288).

Futhermore, Kern and Willcocks (2002) highlights IT outsourcing as "the practice of contracting for mutual benefit and exchange an organization's IT assets, people and/or activities to one or more third party vendors contractually charged with the provision of some or all of the organization's IS functions (processes or services) for monetary payments over an agreed, future time period". Diverse benefits can be gained by IT outsourcing practices such as delivering effective IT-enabled business processes, controlling IT and operating costs, sharing risks, improving organization focus and achieving more value added business outcomes (Insinga and Werle, 2000; Kern and Willcocks, 2002; Cunden, 2008).

Since the economic impacts of IT outsourcing ventures are high for the competitiveness of organizations, governance and management of outsourcing relationship between client and vendor is an increasing need that needs to be considered for enabling the sustainability of the "interaction" and achieving aforementioned benefits of IT outsourcing (Logan, 2000; Schroiff et. al., 2010a; Schroiff et. al., 2010b). Several empirical studies have emphasized the importance of relationship issues on the success of IT outsourcing practices (Schroiff et. al., 2010a; Schroiff et. al., 2010b; Goles and Chin, 2005; Lee and Kim, 1999). Most of the outsourcing practices fail due to the limited ability of parties to work together, mistrustful or lack of communication, discordant conflict resolution. As mentioned in (Schroiff et. al., 2010a: 133; Schroiff et. al., 2010b: 3), social network structure patterns as crucial determinants of outsourcing success take part in shaping the relationship, improving knowledge exchange and strength of collaboration. The link between participating actors in the venture, actors' position in the network, frequency of interaction, the strength of ties and other network measures form the basis of social network structure (Schroiff et. al., 2010b).

This study examines communication dynamics and social network structure characteristics in a case of failed IT outsourcing project from the perspective of client organization. The case project focuses on the maintenance of a Content Management System (CMS) based website which is conducted by a leading digital agency organization as a vendor 
on behalf of a large-scale organization as the client. The aim of outsourcing venture is to support the client in controlling their website content easily and improving digital content management. However, during the project life cycle, it is seen that the poor relationship environments and missing communication strategy plans changed the social network structure severely over time. Thereby this caused informal communication models, inefficient interactions, confusion and lack of confidence between parties; which had a counterproductive effect on the success of the project.

In this regard, this study focuses on outsourcing relationship patterns between client and vendor side in a case study by using valuable constructs described in the literature, and provides interesting potentials to observe constructs of the communication and social network structure, and widens the comprehension of IT outsourcing relationship management. Therewithal, this study tries to reveal how communication models and social network structure dynamics change during the case project lifecycle, and also tries to perceive the needs of participants in an IT outsourcing venture. The study seeks to find out the hidden issues and contributes to the understanding of social network structure's impact on the outcome of IT outsourcing projects from a different viewpoint, in other words from the client organization's perspective.

The structure of the paper is as follows: Section 2 presents relevant research on outsourcing relationship dynamics and social network structure in outsourcing projects. Section 3 explains the research design and methodology including brief information about the case IT outsourcing project. In Section 4, the collected data and research findings on social network structure from the client's perspective are presented by using valuable constructs from existing literature and also with interview notes. Finally, Section 5 provides valuable suggestions and guidelines for the importance of IT outsourcing relationships for researchers and practitioners with research limitations.

\section{RELEVANT RESEARCH}

Several studies have been provided on the exploration of outsourcing relationship for outsourcing project success; however, some particular studies including frameworks address the relationship issue in IT outsourcing empirically and conceptually.

One of the challenging the study provides a good analytical framework for exploring dimensions of IT outsourcing relationships by using Hkansson's “interaction approach" as a guiding conceptual framework (Kern and Willcocks, 2002: 5-6). This exploratory study highlights four major groups of variables which influence the interaction between client- 
vendor; short term exchange factors including products/services, financial, information and social; long term relational factors including adaptation and institutionalization; atmosphere factors formed by power/dependence, cooperation, and closeness, commitment and conflict issues; and environmental factors as market structure, dynamism, social system. Even though the interaction approach study was found too general for organizing the outsourcing relationships, vital and useful constructs within the interaction process and atmosphere were provided by this study. The core part of the model provided by Kern and Willcocks (2002) is the long-term exchange factors and short-term exchange factors, which underpin the interaction process between client and vendor. One of the major contributions of the same study is that short term exchange factors (i.e. products/services, financial, information and social) become some way institutionalized overtime when parties adapt to the outsourcing venture, organizational culture and each other's management style (Kern and Willcocks, 2002: 6). Herein formalization, trust, flexibility and integrity are considered as parts of social (short-term) exchange factors that take a hand in reducing uncertainty, specifically in cultural or spatial disparity conditions.

To understand the social exchange perspective of the IT outsourcing relationships, conceiving the essentials of social network structure, communication and interaction structures, ties between client and vendor as well as the relation between participating individuals need considerable focus. Some valuable measures and constructs have been proposed and performed on how to analyze a social network structure. Another study provides an analysis of social network structure properties and explores its impact on outsourced project success (Schroiff et. al., 2010a: 134; Schroiff et. al., 2010b: 2-3). In accordance with the study, three groups of measures are defined for social networks, which are tie, structural and relational measures. Tie measures concern the connections or relationships between two actors, whereas structural measures focus on the characteristics describing the social network (Schroiff et. al., 2010b: 3). Tie properties focus on the individual connections and relationships between two actors in the network. Actually at this lowest level, during an outsourcing deal, different types of communication structures, knowledge exchange models, trust levels may appear between actors; on the other side creates a diversity of ties. Tie measures are mostly related to the multiplexity of ties, the strength of tie (intensity) and clarity of expectations between two actors (Schroiff et. al., 2010b: 3).

Structural properties are formed by links between actors, and enable them to formalize the interaction and relationships of the actors at the interface level in an outsourcing deal (Schroiff et. al., 2010a: 133; Schroiff et. al., 2010b: 3). At this point, the interface density of 
the network is highlighted since at the interface level between client and vendor, interface the density can range from fully interconnected structure to the gatekeeper model as shown in Figure 2. Structural properties are the highest level of property of a social network. The study of Tichy focuses on structural properties of a social network in four levels; external network, total internal network, clusters within the network and individual within the network (Tichy et. al., 1979: 508).

Beside, relational measures indicate the characteristics of single actors such as roles and responsibilities of the participating actors within the network. The actor's individual position is considered on the social network, which is related to the roles and responsibilities of the actor. At this point, an exploratory stakeholder analysis provides a valuable guide for identifying the participating entities, their information and communication needs, frequency of information required and so on (Berger et. al., 2010: 7). The aim of given stakeholder analysis is to determine who needs information, then what information they need, when they need it and the format in which it should be presented.

According to various studies, the proposed appropriate social structures differ depending on the aforementioned measures. The challenging communication models are the gatekeeper model and the high density of network model as illustrated in Figure 2. However, there is a trade-off between these two social network models; it is still unclear which interaction model is the best. High-density interface models facilitate knowledge exchange between actors in outsourced projects (Koh et. al., 2004: 370); on the other hand gatekeeper as project manager- models promote mainly operational satisfaction and reliability.

Schroiff et. al. (2010b) reviews and compares two different communication models; in any type of collaboration or cooperation of client and vendor, the ideal communication model changes between a centralized model with a single point of contact and a fully interconnected communication model.

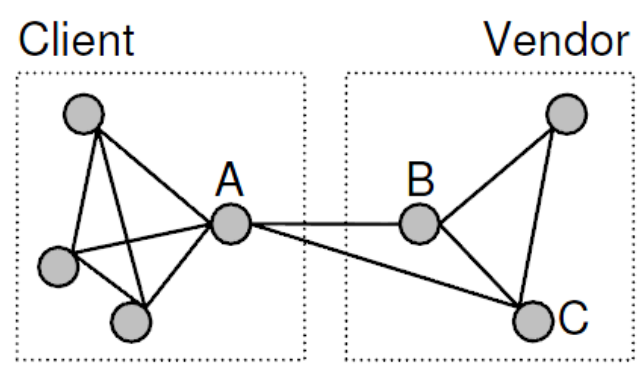

(a) Simple Gatekeeper Model

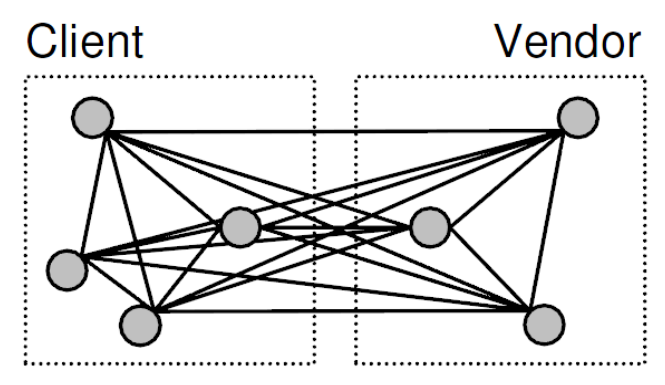

(b) Fully Interconnected Model

Figure 2. Communication Model Types (Schroiff et. al., 2010b) 


\section{RESEARCH DESIGN}

This study conducts a case analysis of a single IT outsourcing practice instead of multiple case research. A single case research allows to gather valuable and elaborative information and provides deep insights to investigate research constructs. In this sense, qualitative research with an interpretative approach is employed in a case IT outsourcing project. In order to assure the validity of qualitative research, multiple data sources are used for collecting the same data about IT outsourcing venture from the client's perspective. Moreover, the study benefits from different types of data collection methods; document reviews, observations and semi-structured interviews with project participants are used to acquire conclusions from qualitative data.

The client organization of the case IT outsourcing project is a large-sized private institution providing management consultancy and training services for public and private national organizations in Turkey. Employing more than 300 people, the organization was established in 1996 by two co-founders with aim of providing training and consultancy services in wide range of areas such as corporate governance and strategy, innovation management, change management, market research, brand and marketing management, business excellence models and programs, value chain and supply chain management, mergers and acquisitions and more. The client organization perceives IT as a supporting activity instead of a core business activity, which makes IT outsourcing practices more reasonable. On the other side, the vendor organization of case outsourcing project is a smallmedium sized digital agency and IT company established in 2002. The company with more than a hundred IT specialists and experts is providing diverse IT consultancy, system development and maintenance, and outsourcing services with a great expertise and IT perception.

The IT outsourcing service provided by the vendor organization in case project targets website maintenance, in other words, a CMS development for managing and improving digital content of the client with a year contractual agreement. The client organization formed a website team for the project including IT department head, website team leader and two IT experts. A Service Level Agreement (SLA) is signed by both parties in November 2017; however, the outsourcing deal was cancelled by mutual decision of both parties and announced as failed project at the Q4 of 2018. The case investigation and data collection was started at the Q3 of 2018 and continued after the cancellation of the project. 
Understanding the outsourcing project in-depth is the very first step of this case research in order to reveal the relationship and social network structure patterns, that are expected to have impacts on outsourcing success. Preliminary data is collected through on a comprehensive literature review. Some valuable tools for analyzing the case context and certain social network structure measures and constructs are identified for understanding the on-going communication and the relationship between client and vendor in an outsourcing deal.

Just after identification of constructs, primary data is collected from document reviews and interviews to achieve a deep understanding of the phenomenon and case context. The outsourcing agreement between client and vendor is explored by using the aforementioned tools in-depth interviews with the project members of the client organization. Semi-structured, face-to-face interviews with three members of the website team in client organization are conducted iteratively. Table 1 presents information about the profile of the interviewees.

Table 1. Interviewees Profile

\begin{tabular}{|c|c|c|c|}
\hline Project Member & Role & $\begin{array}{l}\text { Experience in } \\
\text { Organization }\end{array}$ & $\begin{array}{l}\text { Outsourcing } \\
\text { Experience }\end{array}$ \\
\hline $\begin{array}{l}\text { Website } \\
\text { Team Leader }\end{array}$ & $\begin{array}{l}\text { Works with website team members and } \\
\text { departments on client side; manages and ensures } \\
\text { team to reach its end goal; governs the project } \\
\text { on client side }\end{array}$ & $>10$ years & $>10$ years \\
\hline IT Expert ${ }^{1}$ & $\begin{array}{l}\text { Provides requirements engineering practices and } \\
\text { analysis of website system requirements; have } \\
\text { enough knowledge on system development and } \\
\text { tools; produces requirements documentation and } \\
\text { handles business and technical related requests } \\
\text { of vendor side }\end{array}$ & $>10$ years & 5 years \\
\hline IT Expert ${ }^{2}$ & $\begin{array}{l}\text { Have strong knowledge and skills on system } \\
\text { development and tools; administers and handles } \\
\text { all technical issues of client and vendor side }\end{array}$ & $>10$ years & $>10$ years \\
\hline
\end{tabular}

Results from primary data analysis guided further secondary data collection. As a secondary data source, all exchanged data including electronic mails (648 messages) and reports during the project lifecycle between client and vendor are obtained and examined in order to enhance contextual understanding of the interview results. E-mail is the primary communication medium between participants of this case IT outsourcing project and in this regard, the examination of bulk e-mail content is prominent for perceiving the interactions between client and vendor. 
In the light of collected information, this study briefly tries to examine the following question through a case analysis: How changing social network structure and relationship dynamics affect the performance and outcome of an IT outsourcing practice?

\section{FINDINGS AND DISCUSSION}

In this section, first, general characteristics, attributes and IT perception of the client organization is examined, and profile of the IT outsourcing deal are detailed. Afterward, timeline investigation of communication model is realized; linkages and associations of the key indicators that have theoretical proofing in literature, structural and tie properties of the social network structure are analyzed studiously. With the help of iterative in-depth interviews, critical points of the case project life cycle are clarified that caused substantial changes in the social interaction and communication structure, and caused project failure at last. Finally, the content analysis of exchanged data between parties (i.e., client and vendor participants) puts forward hidden issues, and so allows us to comprehend social network structure's impact on the failure of IT outsourcing projects from client's viewpoint.

\subsection{Case Context Analysis}

The study of Schroiff et al. (2010) provides a valuable guideline for understanding and clarifying the key dimensions of a case context by referencing the studies of Cullen et. al. (2005), Fink (2010), Miranda and Kavan (2005), and Dibbern et. al. (2004). Several attributes regarding the client organization and outsourcing agreement that shape case context are described as seen in Table 2 and Table 3. Concurrently, essential findings that are exposed through iterative in-depth interviews, are presented in third -Interview Notes on Case Contextcolumn. Table 2 explores the outsourcing agreement through nine attributes as constructs, and focuses on the coupling mode and relationship strength between the client and vendor company.

Furthermore, IT perception and approach of the client organization is examined in Table 3. In this regard, two main attributes of Schroiff et al., (2010a: 137) are used; organizational IT value proposition and IT asset proposition.

Moreover, Website Team Leader briefly summarizes the case context as follows: " $U p$ to this project, our IT department has no critical strategic importance across the organization; we just outsource, purchase or lease, and use so fundamental IT services and applications directly. Maintenance requirements of such services are performed once or twice a year by the vendor side. However, this CMS based website project gained critical 
importance for our marketing and sales activities; digital transformation of our content became an essential requirement. The unforeseen issue here is that this outsourcing deal requires a continuous interaction with the vendor side, something that we have not experienced before in this company and this makes our job critical now."

Table 2. Outsourcing Agreement Profile

\begin{tabular}{|c|c|c|}
\hline $\begin{array}{l}\text { Attribute } \\
\text { (Schroiff et al., 2010a: 137) }\end{array}$ & $\begin{array}{l}\text { Description } \\
\text { (Schroiff et al., 2010a: 137) }\end{array}$ & Findings from Interview Notes \\
\hline Scope Grouping & $\begin{array}{l}\text { Scope of the outsourcing arrangement } \\
\text { including services outsourced }\end{array}$ & $\begin{array}{l}\text { Clearly defined scope of the outsourcing } \\
\text { arrangement; a CMS based website } \\
\text { maintenance including clearly defined } \\
\text { outsourced services }\end{array}$ \\
\hline Supplier Grouping & $\begin{array}{l}\text { Number of suppliers and type of } \\
\text { outsourcing contract }\end{array}$ & $\begin{array}{l}\text { Maintenance Service-Level Agreement } \\
\text { (SLA) signed with only one vendor (i.e., } \\
\text { supplier) at } 2017 \text { November }\end{array}$ \\
\hline Financial Scale & $\begin{array}{l}\text { Relative and absolute volume of the } \\
\text { contract which shows the importance } \\
\text { of the arrangement for both parties }\end{array}$ & $\begin{array}{l}\text { Medium financial scale project for client } \\
\text { and vendor perspectives; moderate } \\
\text { importance for both parties }\end{array}$ \\
\hline Pricing Framework & $\begin{array}{l}\text { Method and benchmarks for measuring } \\
\text { performance and calculating payments }\end{array}$ & $\begin{array}{l}\text { No methods used for measuring } \\
\text { performance and pricing framework }\end{array}$ \\
\hline Duration & $\begin{array}{l}\text { Agreed length of contract; important } \\
\text { relationship factor for building ties and } \\
\text { also for the possibility of terminating } \\
\text { the contract }\end{array}$ & $\begin{array}{l}\text { Approximately } 12 \text { months of outsourcing } \\
\text { agreement }\end{array}$ \\
\hline Resource Ownership & $\begin{array}{l}\text { Defines which party controls } \\
\text { resources; shows level of control and } \\
\text { shows how tightly the parties are } \\
\text { coupled }\end{array}$ & $\begin{array}{l}\text { Jointly owned and controlled resources; an } \\
\text { equally shared level of control }\end{array}$ \\
\hline Commercial Relationship & $\begin{array}{l}\text { Relationship structure on } \\
\text { organizational level; formalization of } \\
\text { coupling mode; influences ease of } \\
\text { contract termination and type of } \\
\text { relationships }\end{array}$ & $\begin{array}{l}\text { Weak relationship structure on } \\
\text { organizational level and poor formalization } \\
\text { of coupling mode; ever-increasing troubled } \\
\text { communication over e-mail media; missing } \\
\text { belief in collaboration; violation of trust } \\
\text { over time }\end{array}$ \\
\hline Relational Capability & $\begin{array}{l}\text { Level of processes for knowledge } \\
\text { sharing which are basic factor to build } \\
\text { ties and networks; reflects coupling } \\
\text { mode and goals of the arrangement }\end{array}$ & $\begin{array}{l}\text { No clearly defined and formalized } \\
\text { knowledge sharing process which means } \\
\text { weak tie and network building mechanisms; } \\
\text { mostly performed contacts and knowledge } \\
\text { sharing over e-mail and phone media; } \\
\text { irregular and rare face-to-face meetings }\end{array}$ \\
\hline Internalization & $\begin{array}{l}\text { Level of authority systems defined } \\
\text { which reflects formalization of the } \\
\text { level of control between client and } \\
\text { vendor }\end{array}$ & $\begin{array}{l}\text { No clearly defined and formalized authority } \\
\text { systems between client and vendor; complex } \\
\text { and changing control mechanisms overall } \\
\text { project lifecycle }\end{array}$ \\
\hline
\end{tabular}


Table 3. IT Perception Profile of Client Organization

\begin{tabular}{|l|l|l|}
\hline $\begin{array}{l}\text { Attribute } \\
\text { (Schroiff et al., 2010a: 137) }\end{array}$ & $\begin{array}{l}\text { Description } \\
\text { (Schroiff et al., 2010a: 137) }\end{array}$ & Findings from Interview Notes \\
\hline $\begin{array}{l}\text { Organizational IT Value } \\
\text { Proposition }\end{array}$ & $\begin{array}{l}\text { Strategic role of IT within the } \\
\text { client organization which } \\
\text { reflects goals and expectations } \\
\text { for outsourcing arrangements } \\
\text { and perceived success }\end{array}$ & $\begin{array}{l}\text { Missing IT perception; lack of IT } \\
\text { involvement in strategic decision } \\
\text { making processes (e.g., } \text { outsourcing } \\
\text { decision) }\end{array}$ \\
\hline $\begin{array}{l}\text { Organizational IT Asset } \\
\text { Proposition }\end{array}$ & $\begin{array}{l}\text { Technical and human IT assets } \\
\text { of the client organization which } \\
\text { influences primary motivation } \\
\text { to outsource tasks and success }\end{array}$ & $\begin{array}{l}\text { Only a website team -including four } \\
\text { experts- working directly on the } \\
\text { project with the supplier; perceived it } \\
\text { as a supporting activity rather than } \\
\text { primary (core) activity }\end{array}$ \\
\hline
\end{tabular}

\subsection{Communication Models with Timeline Analysis}

Evolution of the communication model within the case context is examined through observations and interviews. Regarding the communication model, three critical points on the timeline are identified that changed the relationship dynamics and interaction structure between parties over time to a more complex and interconnected structure.

Critical Point (1): A SLA between two companies was prepared and signed for CMS based website maintenance project. However, there is no clearly defined communication strategy plan between client and vendor. At the beginning of the outsourcing deal, gatekeeper communication model between client and vendor was pursued as illustrated in Figure 3. The blue nodes represent the people involving this outsourcing practice on the client side, and the yellow nodes are for the vendor side. Within each entity, the communication is somewhat connected. At the interface level, only one link between gatekeepers of both sides is seen.

CLIENT ORGANIZATION

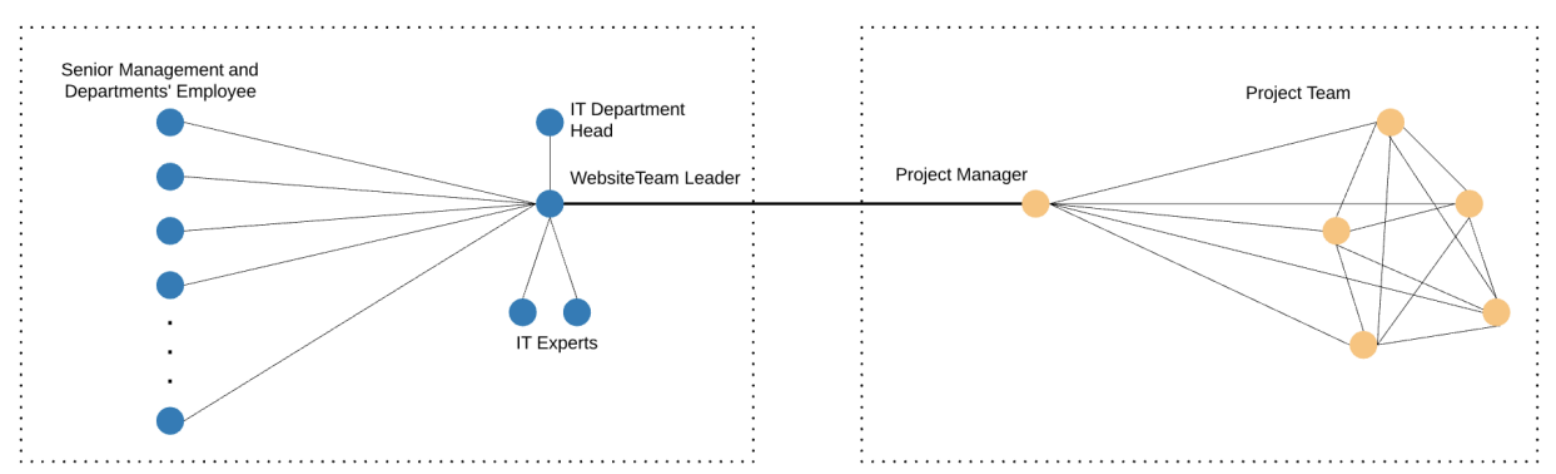

Figure 3. Gatekeeper Communication Model of Case Context (Critical Point 1) 
Regarding interviews, Website Team Leader provided valuable footprints of gatekeeper communication model as follows: "At the beginning, the relationship with the vendor side is only administered by me, acting as the representative of the client side. We are just a small team called Website Team across the organization, consisting of only four experts employed under the Information Processing Center of the organization. We are merely working on this outsourcing project, providing the necessary system requirements to the vendor side; mainly to the Project Manager of the vendor organization. All departments of our organization send their requests -such as adding, updating, deleting contents- directly to me. Later, I filter and delegate tasks to our team members or convey suitable requests to Project Manager of vendor side. The main communication platforms are e-mail and phone media, rather than face-to-face meetings."

Critical Point (2): Two months later, the website team has taken a new, critical decision that affected the overall way of doing business. Every department on the client side started to manage their own website content; that's why every department assigned one Website Representative role who will administer, add, update or delete content related to their department.

Website Team Leader stated that "All staff were sending their website-related request, requirements to me; it seems as a centralized and traceable method. However, only just within two months, it has become very difficult to manage and solve every request one by one and quickly. This has caused accumulation of jobs on the client side. Website representatives of departments started to handle different categories of requests before contacting me. However, most of them had no technical capabilities to handle hard issues."

Furthermore, IT Expert ${ }^{(1)}$ in project team confirmed that "A big majority of website representatives in departments are non-IT experts; therefore in case of technical problems, they conveyed the problem via e-mail or phone to anyone in our team, especially to us -IT experts- to resolve quickly."

Regarding the interviews and observations, the complexity of the relationship and communication model started to alter on the client side. Although, at the interface level, the gatekeeper model was pursued as shown in Figure 4; the interaction model was changed to a more interconnected structure only within the client organization. 


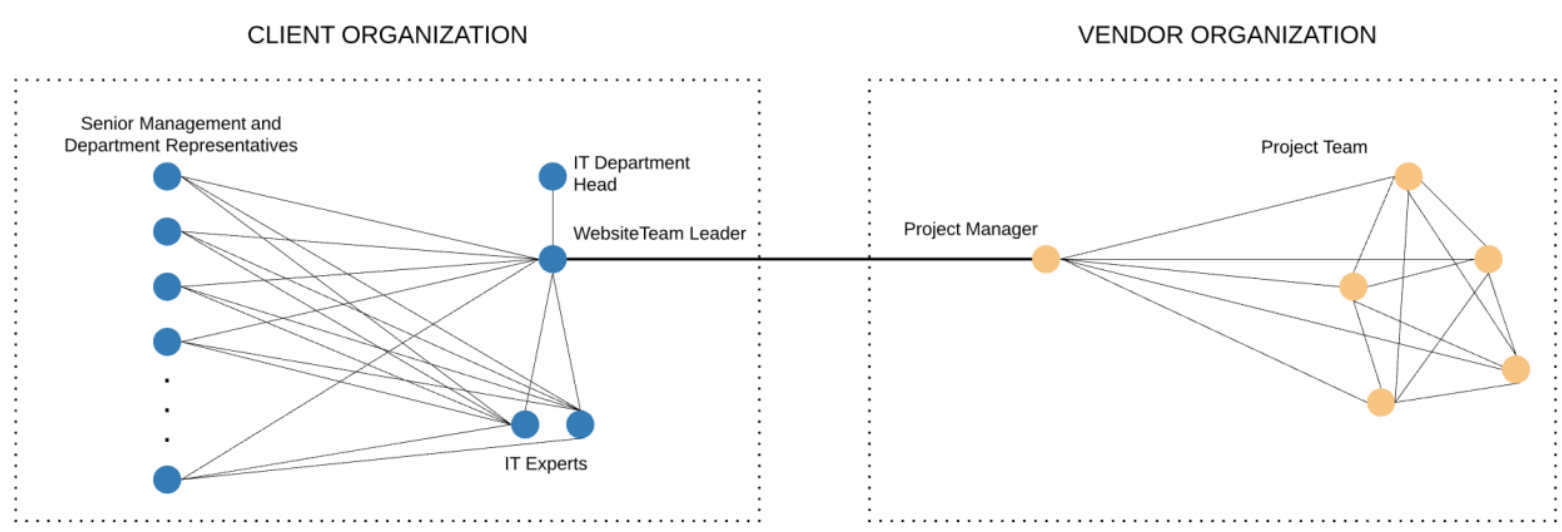

Figure 4. Gatekeeper Communication Model of Case Context (Critical Point 2)

Critical Point (3): After a while -approximately four months- later, the website system started to create technical and managerial problems. As reliability and availability of the outsourced website system increased, website representatives as the business side started to perform high amount of data entrances and to demand new features from the website team members and even from the vendor side. The communication model was started to transform into an interconnected rather than a single gatekeeper in both client and the vendor company as shown in Figure 5. Uncontrolled data entrances and untraceable requests triggered database and infrastructural problems. Existance of too many links as a sign of relationships on client side negatively affected the vendor side; therefore the expected maintenance support was not provided by the vendor.

In this regard, the Website Team Leader stated that "In the beginning, delegating some managerial control to departments seem a good solution for efficient management of the outsourcing deal; unfourtunately, we face some technical and database related problems. In time, decentralizated communication triggered our employees and even our managers to communicate with the vendor side team members directly via phone or e-mail. Our intermediary role as a website team has diminished its impact and importance. Our departments have begun to forward various questions to the vendor side, or sometimes to our website team. As usual, the customer as the business side, wants quick solutions. The requests that were not solved in a short time started to be transmitted to other entities via phone or e-mail. " 


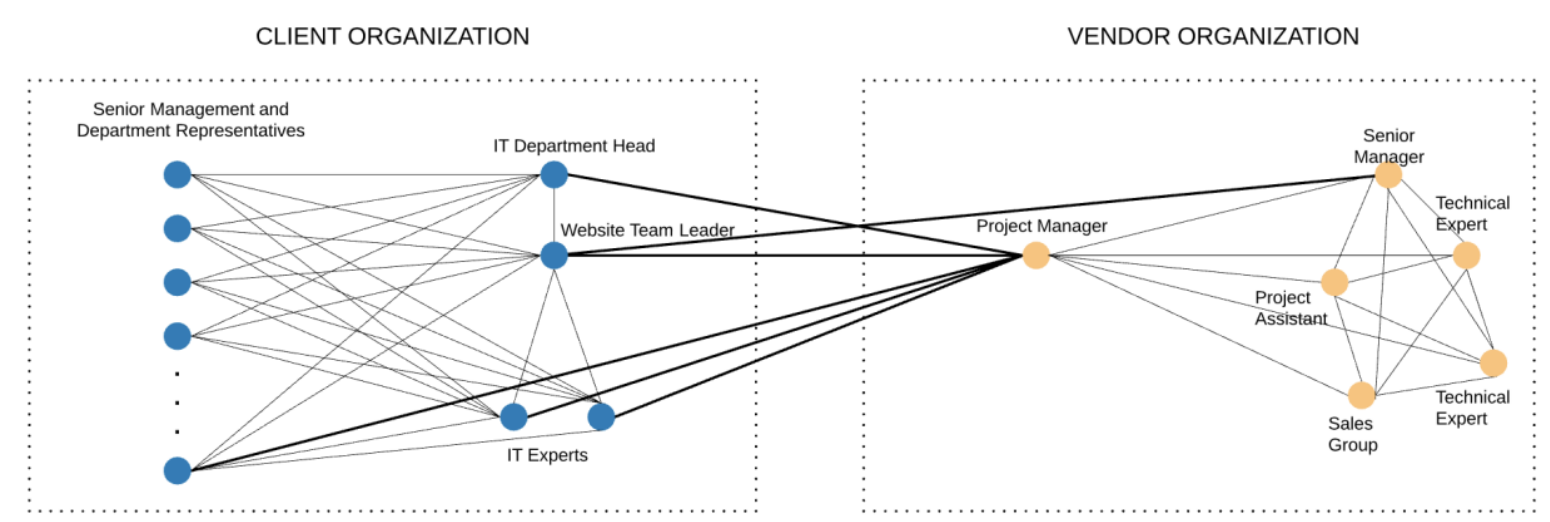

Figure 5. Interconnected Communication Model of Case Context (Critical Point 3)

In this regard, IT Expert ${ }^{(2)}$ in the project team highlighted that "The database was started to include more redundant, outdated data and exceeded its capacity. The problems related to database access were increased. Maintenance support by the vendor became more chaotic in a short time. There was a huge problem of communication, trust and coordination."

Above all, IT Expert ${ }^{(1)}$ indicated that "It was very hard to monitor and track the status of issues or request; who is informed with the problem, who is trying to solve it right now, responsible division, and under which solution stage. You needed to check all the previous emails' forward sections, $c c$ and content parts and so on; and understand the history of the issue. It's like combining the pieces of a puzzle; a waste of time and too many delays in a project."

Website Team Leader also confirmed that "Unfortunately, there is no centralized communication platform for traceability of issues; up to this project we didn't need such an investment for project management. At the beginning, the relationship management and collaboration seemed an easy job for us, but it was not as we expected. Connection of all entities works well, if you have a clearly defined communication strategy plan and platforms; but in this case, not. Too much irregular communications had a great negative impact on the completion of this SLA; each side -our departments, vendor side entities and even our team members- started to blame each other in case of delays or non-replied e-mails. The sense of trust between client and the vendor side was impaired over time."

\subsection{Structural and Tie Measures with Content Analysis}

In addition to iterative in-depth interviews, the examination of exchanged e-mail documents -as critical signs of the knowledge sharing during outsourcing venture- enhances contextual understanding of the interview results and helps to reveal the links between nodes 
in more detail. After the communication model analysis, structural and tie measures are investigated with content analysis on e-mail documents.

To analyze the structural properties, primarily a social network structure in the outsourcing venture is modeled as illustrated in Figure 6. The social network map highlights critical insights about the interaction and relationship structure of project participants. The individuals as special nodes within the network, the clusters and internal network environment are highlighted with their social ties; as essential structural properties of a social network emphasized by Tichy et. al. (1979: 508-509). In accordance with the social structure map of case context, some of the indices describing the structural properties of the model are presented in Table 4.

Regarding tie properties, the exchanged e-mail documents are examined through a content analysis. This technique can be defined as a qualitative research tool that is performed on the artifacts -which is e-mail in this research scope between client and the vendor since the e-mail based interactions are the main communication medium for the project participants of case outsourcing. According to the study of Tichy et. al. (1979), nature of the interactions -in other words, links- can be defined by measures of intensity, reciprocity, clarity of expectations and multiplexity. With the help of content analysis on e-mail communication between client and vendor, relationship changes between nodes and characteristics of intensity, reciprocity and clarity of expectations are examined. 648 e-mail archival documents were grouped in three major categories as given in Table 5; and the tendency of tie properties in content observations is presented in Table 6.

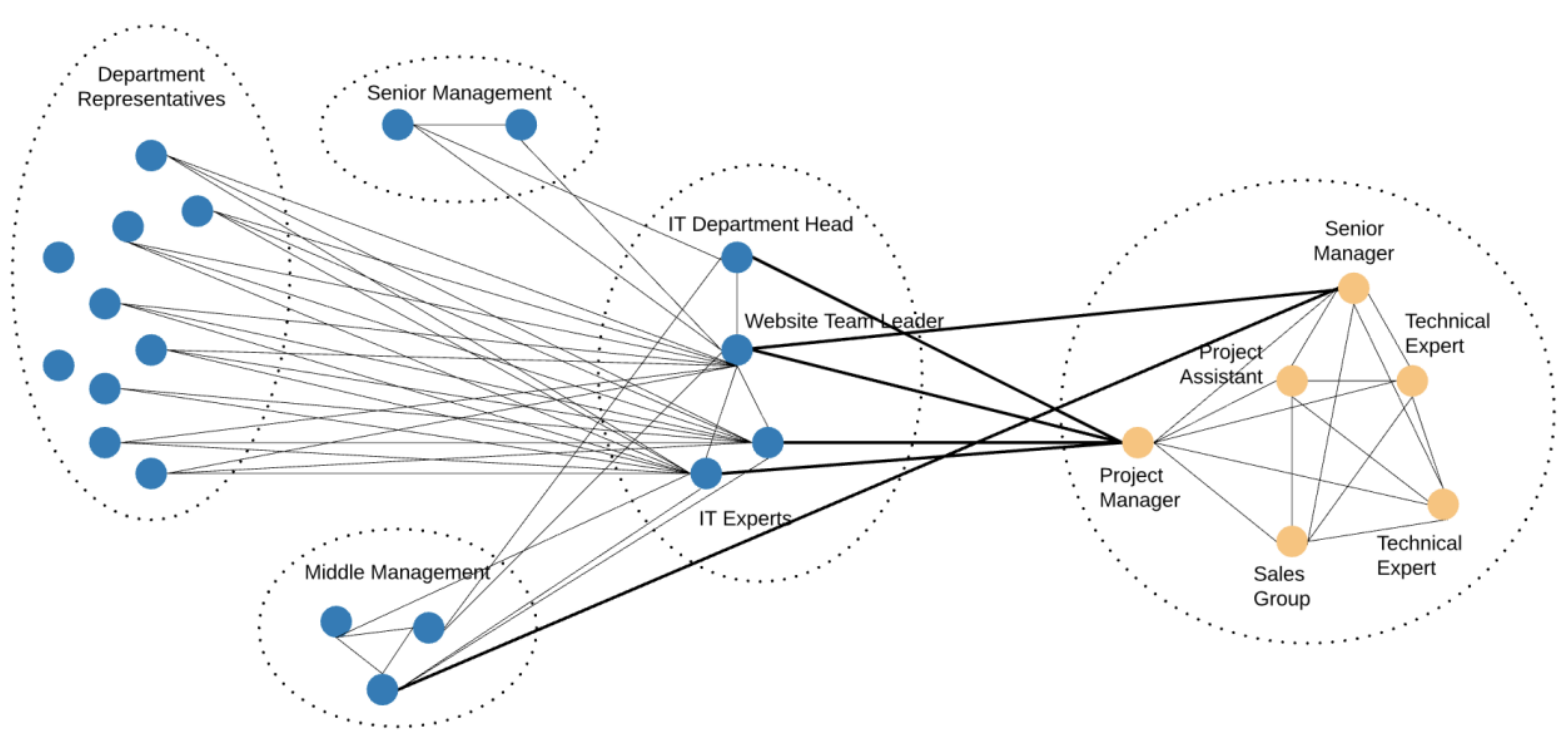

Figure 6. Social Structure Map at the end of IT Outsourcing Practice 
Table 4. Profile of Structural Measures in Case Context

\begin{tabular}{|c|c|}
\hline $\begin{array}{l}\text { Attribute } \\
\text { (Tichy et. al., 1979: 508) }\end{array}$ & Findings from Interview Notes \\
\hline Size & Twenty five nodes participating in the network \\
\hline Density & $\begin{array}{l}\text { Six actual links in the network -as a ratio of the number of possible links- } \\
\text { between client and vendor }\end{array}$ \\
\hline Clustering & Five main dense regions in the network \\
\hline Openness & Actual external links of a social unit is not found clearly \\
\hline Stability & Low stability and dynamic structure \\
\hline Centrality & Low centrality and formal hierarchy; missing centralization \\
\hline Reachability & $\begin{array}{l}\text { Unable to determine the average number of links between any two nodes } \\
\text { in the network; not applicable }\end{array}$ \\
\hline Star & $\begin{array}{l}\text { Website team leader and IT experts on client side having highest number } \\
\text { of nominations }\end{array}$ \\
\hline Bridge & A member of multiple clusters is not found clearly in the network \\
\hline Gatekeeper & Website team leader who links social units \\
\hline Isolate & Two department representatives has uncoupled from the network \\
\hline Liaison & $\begin{array}{l}\text { A member of a cluster linking two or more clusters, is not observed in the } \\
\text { network }\end{array}$ \\
\hline
\end{tabular}

Table 5. Content Analysis Results

\begin{tabular}{|c|c|c|l|}
\hline Category & Number of E-mails & Percentage & Content Categories \\
\hline A & 288 & $44 \%$ & Website content and access control requests \\
\hline B & 256 & $40 \%$ & Database management related requests \\
\hline C & 104 & $16 \%$ & Accounting transaction requests \\
\hline
\end{tabular}


Table 6. Profile of Tie Properties in Content Categories

\begin{tabular}{|c|c|c|c|}
\cline { 2 - 4 } \multicolumn{1}{c|}{} & \multicolumn{3}{c|}{ Content Categories } \\
\hline Tie Properties & Category A & Category B & Category C \\
\hline Intensity & High $\Uparrow \Uparrow$ & High $\Uparrow$ & Low $\Downarrow$ \\
\hline Reciprocity & High $\Uparrow$ & Low $\Downarrow$ & High $\Uparrow$ \\
\hline Clarity of Expectations & Low $\Downarrow$ & Low $\Downarrow$ & High $\Uparrow \Uparrow$ \\
\hline
\end{tabular}

According to the findings from content observations, the highest number of interactions and communication links belongs to Category A. This finding provides insights for social network characteristic of intensity for the study. The proportion (44\%) of Category A signifies that participating actor in the network mostly interacts with each other with regard to CMS access and content adding. Regarding reciprocity measure, Tichy et. al. (1979) states that the relation is commonly perceived and agreed on by all parties to the relation. In content analysis, high reciprocity is observed especially for Category A and Category C, which indicates a high degree of symmetry within communication in these contents. In case of clarity of expectations measure, Categories A and B have poor performance on the clarity of expectations when compared with Category C. Apparently, the individuals who deal with accounting related topics have defined their expectations in messages more clearly and financial requests are handled in time.

As observed from both content analysis and interviews, the main foundation and the purpose of outsourcing deal corroborates with positive tendency -high degree- of both intensity and reciprocity observed in Category A based interactions. Similarly Category B based interactions -including database related requests- demonstrate a high degree of intensity between client and vendor. However, the symmetry of communication is not observed intensively for Category B based interactions. The opposite trend between intensity and reciprocity for Category $\mathrm{B}$ based interactions points out and confirms the problems highlighted in the interviews, especially technical problems occured after the period of Critical Point 2. Additionally, in the high frequency of interactions -in other words in both categories of $\mathrm{A}$ and $\mathrm{B}$ based interactions- the requests were not explicitly defined and addressed; unclarity of expectations may be a cause of relationship problems and mistrustful communication environment happened over time. Unclarity of expectations has a notable effect on the outsourcing project outcome as observed during interviews. Category $\mathrm{C}$ based interactions show the least problematic links, collaborative environment and trustful 
communication with the positive tendency -high degree- of both communication symmetry and clarity of expectations; therefore frequency of interactions for Category $\mathrm{C}$ is lower than the other categories. The assessment of tie properties in terms of content analysis on communication medium provides valuable insights to comprehend relationship problems that have a considerable impact on project performance.

Multiplexity is another essential tie property of Tichy et. al. (1979) which is assessed for each individual instead of focusing on contents; it is the degree to which pairs of individuals are linked by multiple roles. This characteristic changes for each participating actor; therefore within the study scope, it is difficult to observe and define a degree for multiplexity; this part is one of the limitations of this study.

\section{CONCLUSION}

This study aims to perform an examination of a failed outsourcing case in terms of communication model and social network structure characteristics. With this design, the structural and tie properties of the social network in question are explored. To answer the purpose, the study focused on some parameters that have theoretical proofing in literature and all given measures for describing the patterns of a social network structure which are helpful in analyzing outsourcing deal.

The study shows that both communication models have challenging issues during outsourcing practice, although interconnected communication model has theoretical proof regarding the advantages in an outsourcing context. It is obvious to say that the communication model itself does not create a complete success for an outsourcing project; some considerable factors can contribute for IT outsourcing relationship and IT outsourcing success, in particular expertness of participating actors, client's technical infrastructure convenience of client side and readiness for IT outsourcing.

Furthermore, the content analysis on the exchanged documents manifests that with the interconnected communication model, high degrees of clarity of expectations and reciprocity can show signs of a positive relationship attitude, trustful and collaborative environment between parties; which means less problems and lower frequency of interaction for that specific issue or request. On the other side, the contents including high frequency of irregular and informal interactions can demonstrate significant sources of a counterproductive effect on the success of the project.

The high degrees of both intensity and symmetry of communication observed in the access control and web content management issues serve and support the outsourcing project 
objectives. It is seen that both sides trying to handle managerial issues of the deal. However, observed weakness in clarity of expectations can be a cause of confusion and lack of confidence, unwillingness to perform, mistrustful communication environment between parties.

In addition, the weakness in clarity of expectations and reciprocity demonstrates another important sign for outsourcing relationship. As technical problems on client side started to emerge, the clarity of expectations and symmetry of communication started to scale down which triggered a more interconnected communication model with a high degree of intensity, in other words, high frequency of interactions by client side.

The limitation behind this case analysis is that interactions or links between each pair of individuals cannot be investigated in depth due to the complex network structure and dynamic communication model; hereby limited amount of interviews on client organization were conducted.

In conclusion, this case study provides interesting insights on IT outsourcing relationships, communication models and the impact of social interactions on the performance and outcome of an outsourcing project. This study can be adapted and studied on different IT outsourcing projects from both client and vendor perspectives and also with more field explorations in the quantitative approach. 


\section{REFERENCES}

Berger, H. et. al. (2010), "Outsourcing and Communications, the Role of Stakeholder Analysis - A Case Study in Practice”, AMCIS 2010 Proceedings, 66, pp. 1-11.

Cullen, S. et. al. (2005), "IT Outsourcing Configuration: Research into Defining and Designing Outsourcing Arrangements", The Journal of Strategic Information Systems, 14 (4), pp. 357-387.

Cunden, M. (2008), "The Impact of the IT Outsourcing Relationship on the Success of the Venture: A Research Agenda", ECIS Proceedings, 64, pp. 1-13.

Dibbern, J. et. al. (2004), "Information Systems Outsourcing: A Survey and Analysis of the Literature", The DATABASE for Advances in Information Systems, 35 (4), pp. 6-102.

Djavanshir, G. R. (2005). Surveying the risks and benefits of IT outsourcing. IT professional, 7(6), 3237.

Fink, L. (2010), “Information Technology Outsourcing through a Configurational Lens”, Journal of Strategic Information Systems, 19, pp. 124-141.

Goles, T. and Chin, W. W. (2005), "Information Systems Outsourcing Relationship Factors: Detailed Conceptualization and Initial Evidence”, SIGMIS Database, 36 (4), pp. 47-67.

Hu, Q., Saunders, C., \& Gebelt, M. (1997). Diffusion of information systems outsourcing: A reevaluation of influence sources. Information Systems Research, 8(3), 288-301.

Insinga, R.C. and Werle, M. J. (2000), "Linking outsourcing to business strategy", Academy of Management Perspectives, 14 (4), pp. 58-70.

Kern, T. and. Willcocks, L. P. (2002), "Exploring Relationships in Information Technology Outsourcing: The Interaction Approach”, European Journal of Information Systems, 11 (1), pp. 3-19.

Koh, C. et. al. (2004), "IT Outsourcing Success: A Psychological Contract Perspective", Information Systems Research, 15 (4), pp. 356-373.

Lee, J. N. and Kim, Y. G. (1999), "Effect of Partnership Quality on IS Outsourcing Success: Conceptual Framework and Validation", Journal of Management Information Systems, 15 (4), pp. 2962 .

Logan, M. S. (2000), "Using Agency Theory to design successful outsourcing relationships", International Journal of Logistics Management, 11 (2), pp. 21-32.

Loh, L., \& Venkatraman, N. (1992). Determinants of information technology outsourcing: a crosssectional analysis. Journal of management information systems, 9(1), 7-24.

Loh, L., \& Venkatraman, N. (1995). An empirical study of information technology outsourcing: Benefits, risks, and performance implications. ICIS 1995 Proceedings, 25.

Looff, L.A. de. "A model for information systems outsourcing decision making", PhD Dissertation TU Delft, September 19, 1996. 
Miranda, S. M. and Kavan, C. B. (2005), "Moments of Governance in IS Outsourcing: Conceptualizing Effects of Contracts on Value Capture and Creation", Journal of Information Technology, 20 (3), pp. 152-169.

Schroiff, A. et. al. (2010), "Structuring the structure in outsourcing research - A social network perspective on outsourcing relationship management", Proceeding of the 16th Americas Conference on Information Systems, pp. 1-9.

Schroiff, A. et. al. (2010), "The Role of Social Network Structures in Outsourced Projects", International Research Workshop on IT Project Management, pp. 132-141.

Statista (2018). Top reasons why companies outsource information technology (IT) services worldwide in 2018. Retrieved from https://www.statista.com/statistics/948977/technologyoutsourcing-top-reasons-globally/

Tichy, N. M., Tushman, M. L. and Fombrun, C. (1979), "Social Network Analysis for Organizations", The Academy of Management Review, 4 (4), pp. 507-519.

Weinert, S. and Meyer, K. (2005), "The evolution of IT outsourcing: From its origins to current and future trends", Bergische Univ. Wuppertal, 202, pp. 1-30. 